\title{
PENGARUH BOOK TAX DIFFERENCES DAN ARUS KAS TERHADAP PERTUMBUHAN LABA
}

\author{
Erika Ratih Windarti \\ Dwi Sulistiani \\ Jurusan Akuntansi Fakultas Ekonomi \\ Universitas Islam Negeri Maulana Malik Ibrahim Malang \\ Jl. Gajayana No. 50, Tlp 0341-558881 \\ e-mail: tiaraakbar2006@yahoo.com
}

Abstract

This study aimed to obtain empirical results about the influence of book tax differences and cash flow toward the profit growth. Independent variables in this study were book tax differences which were proxied to be permanent differences and temporary differences, as well as the cash flow. Control variables used are return on assets (ROA) and the size of the company. The dependent variable was earnings growth. Method of sample selection used was the purposive sampling method and obtained samples of 27 companies. This test was using SPSS V 21 for Windows. The results showed that the permanent difference and temporary differences of the book tax differences have positive influence on the profit grouth of the company, while cash flow did not significantly influence the company's profit growth.

Keywords: book tax differences, cash flow, profit growth

Abstrak

Penelitian ini bertujuan untuk memperoleh hasil empiris tentang pengaruh book tax differences dan arus kas terhadap pertumbuhan laba. Variabel independen dalam penelitian ini antara lain book tax differences yang diproksikan menjadi beda permanen dan beda temporer, serta arus kas. Variabel kontrol yang digunakan adalah Return On Assets (ROA) dan ukuran perusahaan. Sedangkan variabel 
dependennya adalah pertumbuhan laba. Analisis data dengan menggunakan regresi berganda (Ordinary Least Square). Hasil penelitian menunjukkan bahwa beda permanen dan beda temporer dari book tax differences serta arus kas berpengaruh positif terhadap pertumbuhan laba perusahaan. ROA dan ukuran perusahaan tidak berpengaruh signifikan terhadap pertumbuhan laba.

Kata kunci: book tax differences, arus kas, pertumbuhan laba

\section{PENDAHULUAN}

Perusahaan dalam melaksanakan kegiatan usahanya akan menyusun laporan keuangan pada akhir periode akuntansi. Menurut PSAK no. 1 paragraf 7 tahun 2013 tentang Penyajian Laporan Keuangan, laporan keuangan adalah suatu penyajian terstruktur dari posisi keuangan dan kinerja keuangan dan hasil operasi perusahaan. Laporan keuangan tidak hanya digunakan perusahaan atau pihak manajemen tetapi juga digunakan oleh pihak-pihak lain seperti pemilik perusahaan, investor, kreditur, pemerintah, karyawan dan masyarakat. Investor misalnya, menggunakan laporan keuangan sebagai dasar dalam pengambilan keputusan investasi yang berkaitan dengan keuangan perusahaan. Investor menggunakan informasi laba atau rugi dari laporan keuangan sebagai indikator berhasil atau tidaknya perusahaan dalam melaksanakan usahanya. Lewat laporan laba rugi, kreditur juga mempertimbangkan kelayakan kredit debitur, sedangkan pemerintah menggunakan laporan laba rugi sebagai dasar penetapan pajak yang nantinya akan disetorkan ke kas negara.

Bagi pemerintah, laba yang dilaporkan perusahaan akan dijadikan acuan atau dasar dalam penetapan pajak perusahaan. Sering kali perusahaan membuat dua laporan keuangan berbeda, yaitu laporan keuangan yang digunakan oleh manajemen sendiri dan laporan yang digunakan untuk dasar penetapan pajak. Hal ini terjadi karena adanya perbedaan perlakuan pengakuan dalam perhitungan laba menurut akuntansi dan menurut aturan perpajakan. Perbedaan peraturan tersebut akan mengakibatkan adanya perbedaan laba antara laba akuntansi atau laba komersial dengan laba menurut pajak atau laba fiskal, atau sering disebut dengan istilah book-tax differences.

Beberapa peneliti, baik di luar negeri ataupun di Indonesia telah melakukan penelitian kemungkinan book tax differences menjadi sumber informasi yang berguna bagi pengguna laporan keuangan. Wijayanti (2006) mengungkapkan bahwa book tax difference secara negatif berpengaruh signifikan terhadap persistensi laba akuntansi satu periode ke depan. Penelitian pengaruh book tax difference terhadap pertumbuhan laba juga banyak dilakukan. Jackson (2005) membuktikan bahwa book tax difference berpengaruh terhadap pertumbuhan laba dan mengandung informasi mengenai kinerja masa depan. 
Pertumbuhan laba adalah prosentase kenaikan laba yang diperoleh perusahaan (Saputro, 2011). Sedangkan persistensi laba adalah revisi laba yang diharapkan di masa mendatang yang tercermin dalam laba periode berjalan (Asma, 2013). Pemilihan variabel pertumbuhan laba dalam penelitian adalah karena pertumbuhan laba merupakan parameter penilaian kinerja perusahaan.

Faktor lain yang mungkin mempengaruhi pertumbuhan laba adalah arus kas. Menurut Hery (2009:201), informasi arus kas dapat memberikan gambaran mengenai hasil kinerja perusahaan yang sesungguhnya selama periode tertentu. Informasi arus kas mungkin bermanfaat dan memiliki pengaruh terhadap pertumbuhan laba perusahaan karena laporan arus kas memberikan informasi apapun yang ingin diketahui mengenai kinerja perusahaan selama periode tertentu. Laporan arus kas juga dapat digunakan sebagai alat untuk menganalisis apakah rencana perusahaan dalam hal investasi dan pembiayaan telah berjalan sebagaimana mestinya (Hery, 2009:202).

Dalam penelitian ini juga digunakan variabel kontrol, yaitu Return On Assets (ROA) dan ukuran perusahaan (size). ROA diperkirakan akan mempengaruhi pertumbuhan laba. ROA merupakan salah satu rasio profitabilitas yang digunakan untuk mengukur efektivitas perusahaan di dalam menghasilkan keuntungan dengan memanfaatkan total aset yang dimilikinya. Sedangkan ukuran perusahaan atau size adalah suatu skala di mana dapat diklasifikasikan besar kecilnya suatu perusahaan dengan berbagai cara. Ukuran perusahaan dijadikan variabel kontrol karena Manzon dan Plesko dalam Martani dan Persada (2009) menyatakan bahwa ukuran perusahaan dapat memberikan efek noise dimana perusahaan dapat melakukan tax planning antara lain dengan cara investasi aktiva yang memberikan manfaat pajak secara efektif sehingga efek dari book tax difference menjadi agak bias.

Penelitian pengaruh book tax difference terhadap pertumbuhan laba telah banyak dilakukan. Jackson (2005) membuktikan bahwa book tax difference berpengaruh terhadap pertumbuhan laba dan mengandung informasi mengenai kinerja masa depan. Pendapat ini didukung dengan penelitian yang dilakukan oleh Saputro (2011), bahwa total book tax difference mampu memprediksi pertumbuhan laba satu periode ke depan. Hutabarat (2013) juga mengungkapkan bahwa book tax difference berpengaruh signifikan negatif terhadap pertumbuhan laba. Hasil penelitian-penelitian tersebut berbeda dengan penelitian yang dilakukan oleh Lestari (2011), bahwa perbedaan permanen maupun perbedaan temporer dari book tax difference tidak memiliki pengaruh signifikan terhadap pertumbuhan laba. Hal yang sama diungkapkan oleh Oktafioni, Ethika dan Rahmawati (2013) serta Amelia, Zirman dan Diyanto (2014). 


\section{TINJAUAN PUSTAKA}

\section{Beda Permanen}

Beda permanen sebagai salah satu pembentuk book tax differences dapat mempengaruhi besar kecilnya laba bersih yang dihasilkan perusahaan. Hal ini disebabkan oleh adanya koreksi fiskal, baik koreksi positif atau negatif. Koreksi positif akan menambah laba fiskal. Menurut Amelia, Zirman dan Diyanto (2014)

Beda permanen berpengaruh signifikan positif tehadap pertumbuhan laba. Hasil yang berbeda diungkapkan oleh Brolin dan Rohman (2014) yang menyatakan bahwa beda permanen memiliki pengaruh yang tidak signifikan terhadap pertumbuhan laba. Pendapat ini didukung oleh Lestari (2011), Saputro (2011) dan Oktafioni, Ethika dan Rahmawati (2012).

\section{Beda Temporer}

Beda temporer sebagai pembentuk book tax differences, sama halnya dengan beda permanen, akan menyebabkan adanya koreksi fiskal baik positif maupun negatif. Apabila dikoreksi positif, kemudian menyebabkan laba fiskal bertambah. Menurut Amelia, Zirman dan Diyanto (2014) beda temporer berpengaruh negatif tehadap pertumbuhan laba namun tidak signifikan. Menurut Oktafioni, Ethika dan Rahmawati (2012) beda temporer berpengaruh postif tetapi tidak signifikan. Hasil ini sama dengan penelitian yang dilakukan oleh Lestari (2011). Sedangkan dalam penelitian yang dilakukan oleh Saputro (2011), beda temporer berpengaruh signifikan negatif terhadap pertumbuhan laba. Brolin dan Rohman (2014) menunjukkan bahwa beda temporer berpengaruh signifikan positif terhadap pertumbuhan laba.

\section{Informasi Arus Kas}

Informasi arus kas berguna bagi entitas untuk menilai kemampuannya dalam menghasilkan kas atau setara kas dan berguna untuk menilai atau membandingkan arus kas masa datang. Asma (2013) dalam penelitiannya mengungkapkan bahwa arus kas berpengaruh positif terhadap persistensi laba. Amelia, Zirman dan Diyanto (2014) juga mengungkapkan bahwa arus kas berpengaruh positif terhadap perubahan laba pada perusahan. Menurut Prastowo (2011:32), laporan informasi arus kas operasi dapat dijadikan alat pengecekan atas informasi laba dan sebagai pengukur kinerja perusahaan. Kinerja perusahaan ini dapat dilihat dari pertumbuhan laba perusahaan. Laporan arus kas membantu para pemakai untuk mengetahui alasanalasan perbedaan antara laba bersih atau laba akuntansi dengan laba tunainya.

\section{Return On Asset}

ROA diperkirakan akan mempengaruhi persistensi laba. Pada penelitianpenelitian sebelumnya, menyatakan bahwa ROA memiliki pengaruh yang signifikan 
positif terhadap pertumbuhan laba. Hasil ini diungkapkan oleh Lestari (2011), didukung dengan hasil penelitian yang dilakukan oleh Hutabarat (2013), Brolin dan Rohman (2014). Sedangkan menurut penelitian Saputro (2011), ROA memiliki pengaruh yang signifikan negatif terhadap pertumbuhan laba.

\section{Ukuran Perusahaan}

Manzon dan Plesko (dalam Martani dan Persada, 2009: 8) menyatakan bahwa ukuran perusahaan dapat memberikan efek noise dimana perusahaan dapat melakukan tax planning antara lain dengan cara investasi aset yang memberikan manfaat pajak secara efektif sehingga efek dari book tax differences menjadi agak bias. Perusahaan besar dianggap mempunyai lebih banyak informasi dibandingkan dengan perusahaan kecil. Menurut Saputro (2011), ukuran perusahaan tidak berpengaruh terhadap pertumbuhan laba. Pendapat tersebut didukung oleh Brolin dan Rohman (2014). Menurut Hutabarat (2013), ukuran perusahaan berpengaruh negatif terhadap pertumbuhan laba perusahaan.

\section{Persepektif Islam}

Laba merupakan salah satu tujuan yang ingin dicapai perusahaan. Laba merupakan hal yang sangat penting dalam perusahaan karena laba dapat dijadikan sebagai informasi bagi para pemegang kepentingan serta dapat digunakan untuk kepentingan investasi. Laba seringkali dilihat sebagai suatu ukuran berhasil atau tidaknya manajemen dalam menjalankan usahanya.

Dalam Islam, juga telah dijelaskan mengenai masalah laba atau keuntungan. Sesuai dengan firman Allah dalam QS. Al Jumu'ah (62) ayat 10, yaitu:

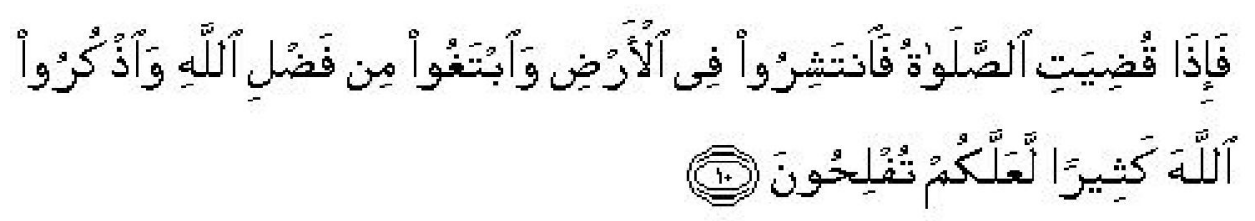

Artinya: "apabila telah ditunaikan shalat, Maka bertebaranlah kamu di muka bumi; dan carilah karunia Allah dan ingatlah Allah banyak-banyak supaya kamu beruntung."

Berdasarkan ayat di atas, dapat dilihat bahwa Allah memerintahkan manusia untuk bertebaran di muka bumi dan mencari karunia Allah, dalam hal ini berkaitan dengan urusan duniawi, misalnya jual beli, mencari rezeki yang halal. Manusia diharapkan selalu mengingat Allah dalam melakukan usahanya, senantiasa jujur dan menghindari diri dari segala bentuk kecurangan. 
Ayat ini dapat menjelaskan bahwa mencari rezeki atau keuntungan adalah hal yang tidak dilarang. Perusahaan dalam operasionalnya juga senantiasa mencari keuntungan atau laba. Ayat tersebut dapat dijadikan acuan bahwa Allah senantiasa memerintahkan manusia untuk mencari rezeki dan karunia Allah dengan cara yang baik.

Terdapat beberapa aturan tentang laba dalam konsep Islam menurut Syahatah (2001:147) dalam Nila (2013), antara lain: (1) Adanya harta yang dikhususkan untuk perdagangan. (2) Modal dioperasikan secara interaktif dengan unsur-unsur lain yang terkait untuk produksi, seperti usaha dan sumber-sumber alam.(3) Memposisikan harta sebagai objek dalam pemutarannya karena adanya kemungkinankemungkinan pertambahan dan pengurangan jumlahnya. (4) Selamatnya modal pokok, artinya modal dapat dikembalikan.

Berdasarkan konsep tersebut dan dihubungkan dengan ayat al Quran di atas, terdapat kesesuaian yaitu Allah memerintahkan manusia, termasuk dalam pembahasan ini adalah perusahaan, untuk mencari laba, dalam bentuk rezeki dan karunia Allah dengan cara yang baik dan perusahaan mengoperasikan modalnya dengan unsur-unsur lain yang terkait dengan proses produksi dan perdagangan, misalnya untuk usaha sesuai dengan firman Allah dalam QS. aN-Nisa ayat 29, yaitu:

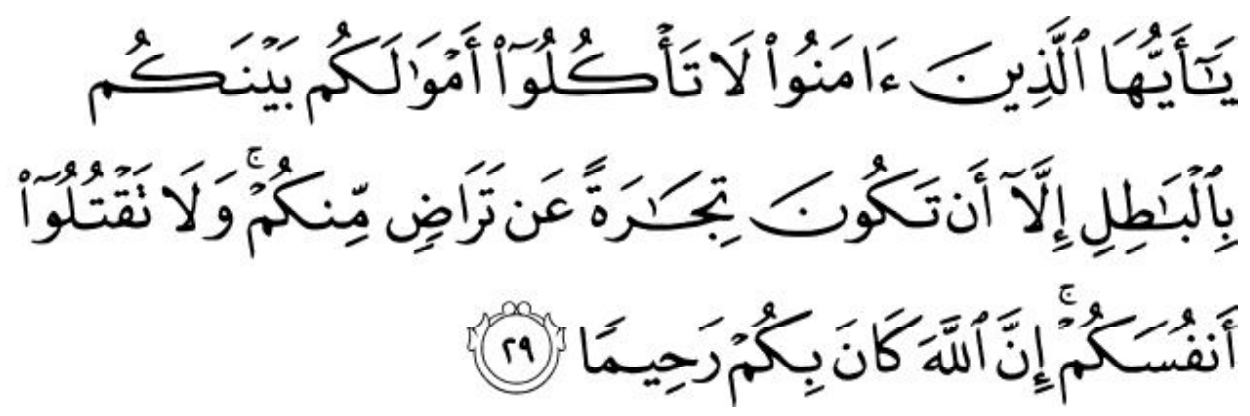

Artinya: "Hai orang-orang yang beriman, janganlah kamu saling memakan harta sesamamu dengan jalan yang batil, kecuali dengan jalan perniagaan yang berlaku dengan suka sama-suka di antara kamu. dan janganlah kamu membunuh dirimu; sesungguhnya Allah adalah Maha Penyayang kepadamu."

\section{Hipotesis}

$\mathrm{H} 2 \mathrm{~b}$ : Beda permanen berpengaruh positif terhadap pertumbuhan laba perusahaan $\mathrm{H} 1 \mathrm{~b}$ : Beda temporer berpengaruh positif terhadap pertumbuhan laba perusahaan $\mathrm{H} 2$ : Arus kas berpengaruh positif terhadap pertumbuhan laba perusahaan

H3 : ROA sebagai variabel kontrol berpengaruh positif terhadap pertumbuhan laba perusahaan 
H4 : Ukuran perusahaan (size) sebagai variabel kontrol berpengaruh negatif terhadap pertumbuhan laba perusahaan

\section{METODOLOGI PENELITIAN}

Penelitian ini menggunakan metode deskriptif kuantitatif. Populasi dalam penelitian ini adalah seluruh perusahaan manufaktur yang terdaftar di Bursa Efek Indonesia sampai dengan Februari 2015, yang berjumlah 141 perusahaan. Pengambilan sampel dilakukan dengan metode purposive sampling. Metode analisis data yang digunakan adalah metode analisis regresi berganda dengan bantuan software SPSS 21 for Windows.

Variabel yang digunakan dalam penelitian ini adalah variabel dependen yaitu pertumbuhan laba (Y), variabel independen yaitu beda permanen dari book tax differences (X1a), beda temporer dari book tax differences (X1b), arus kas (X2), dan variabel kontrol yaitu Return On Assets (X3) dan ukuran perusahaan (X4).

\section{HASIL PENELITIAN DAN PEMBAHASAN}

\section{Hasil Analisis Statistik Deskriptif}

Tabel 1. Hasil Uji Statistik Deskriptif

escriptive Statistics
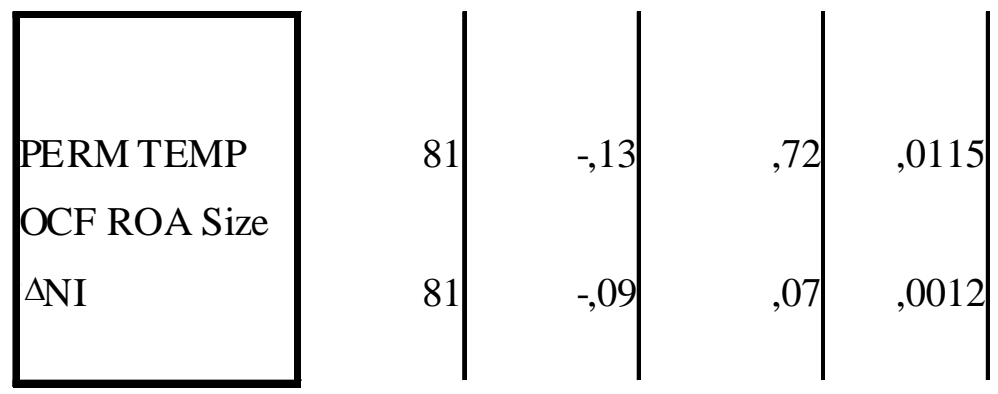

, 09779

Sumber: Output SPSS, 2015

Dapat dilihat dalam tabel tersebut, jumlah observasi $(\mathrm{N})$ dari penelitian ini adalah 81 perusahaan. Berdasarkan keseluruhan jumlah observasi tersebut, pertumbuhan laba $(\Delta \mathrm{NI})$ menunjukkan nilai minimum sebesar -0,26 yaitu perusahaan MLBI (PT Multi Bintang Indonesia Tbk) tahun 2013, nilai maksimum 0,61 juga oleh perusahaan MLBI (PT Multi Bintang Indonesia Tbk) tahun 2012, nilai ratarata sebesar 0,0169 dan standar deviasinya sebesar 0,08305. Ini menunjukkan adanya variasi dalam pertumbuhan laba perusahaan. Artinya, terdapat perubahan kenaikan dan penurunan laba dalam setiap periode pengamatan. 


\section{Hasil Uji Asumsi Klasik}

Berdasarkan hasil uji asumsi klasik nilai signifikansi sebesar 0,253 berarti data berdistribusi secara normal. Variance Inflation Factors (VIF) dari semua variabel menunjukkan nilai yang tidak melebihi 10 serta nilai tolerance yang mendekati 1 . Hal ini berarti tidak terjadi masalah multikolinieritas dalam model ini. Nilai D-W sebesar 1,991. Yang menunjukkan bahwa tidak terjadi masalah autokorelasi dalam model penelitian ini, dan yang terakhir menunjukkan hasil pengujian heteroskedastisitas dengan uji Glejser menunjukkan nilai signifikansi dari seluruh variabel memiliki nilai signifikansi lebih besar dari 0,05 . Hal tersebut menunjukkan tidak terjadi masalah heteroskedastisitas dalam model penelitian ini.

\section{UJI HIPOTESIS}

\section{Hasil Analisis}

Metode analisis data yang digunakan adalah regresi linier berganda dengan metode analisis Ordinary Least Square (OLS) dengan bantuan program SPSS 21 for Windows. Persamaan regresi dalam penelitian adalah:

$\mathrm{Ln} \Delta \mathrm{NI}=-0,041+0,208 \mathrm{PERM}+1,425 \mathrm{TEMP}+0,186 \mathrm{OCF}-0,024 \mathrm{ROA}+0,03$ Size $+\varepsilon$

Tabel 2. Hasil Persamaan Uji Regresi OLS

\section{Coefficients $^{\mathrm{a}}$}

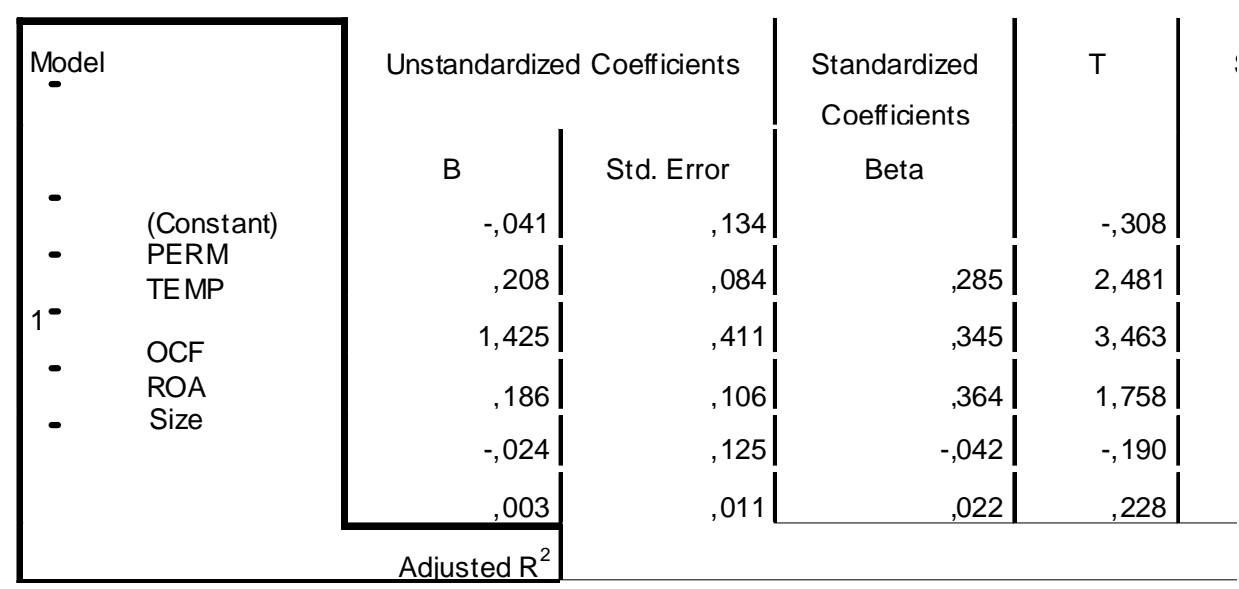

a. Dependent Variable: $\operatorname{Ln} \Delta N I$

Sumber: Output SPSS, 2015 
Berdasarkan tabel di atas dapat dipahami bahwa koefisien sebesar -0,041 menunjukkan bahwa jika tidak ada variabel beda permanen, beda temporer, arus kas, ROA dan ukuran perusahaan maka pertumbuhan laba adalah sebesar -0,041 dengan syarat variabel lain yang ikut mempengaruhi pertumbuhan laba dianggap konstan. Koefisien beda permanen sebesar 0,028 menunjukkan bahwa setiap kenaikan satu satuan pada variabel beda permanen, pertumbuhan laba perusahaan akan meningkat sebesar 0,028 satuan dengan variabel lain dianggap konstan. Koefisien beda temporer sebesar 1,425 menunjukkan bahwa setiap kenaikan satu satuan pada variabel beda temporer, pertumbuhan laba perusahaan akan meningkat sebesar 1,425 satuan dengan variabel lain dianggap konstan. Koefisien arus kas/operating cash flow (OCF) sebesar 0,186 menunjukkan bahwa setiap kenaikan satu satuan pada variabel arus kas, pertumbuhan laba perusahaan akan meningkat sebesar 0,186 satuan dengan variabel lain dianggap konstan. koefisien Return On Assets (ROA) sebesar -0,024 menunjukkan bahwa setiap kenaikan satu satuan pada variabel ROA, pertumbuhan laba perusahaan akan menurun sebesar 0,024 satuan dengan variabel lain dianggap konstan. koefisien ukuran perusahaan (size) sebesar 0,03 menunjukkan bahwa setiap kenaikan satu satuan pada variabel ukuran perusahaan, pertumbuhan laba perusahaan akan meningkat sebesar 0,03 satuan dengan variabel lain dianggap konstan.

\section{Uji Statistik F}

\section{Tabel 3. Hasil Uji F}
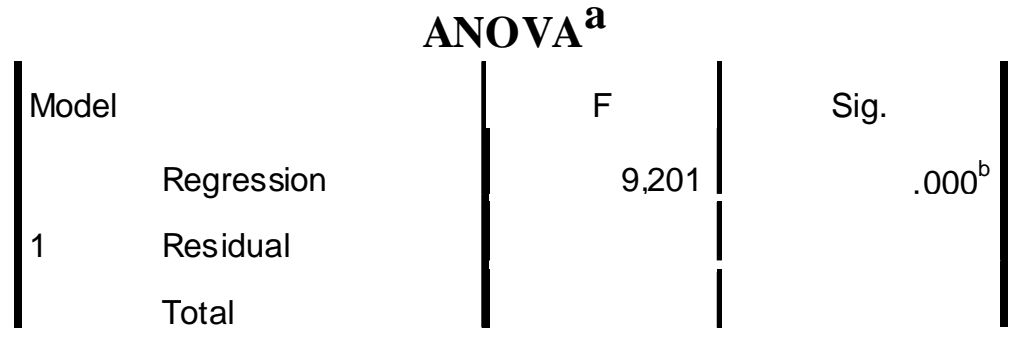

a. Dependent Variable: $L n+N I$

b. Predictors: (Constant), Size, TEMP, OCF, PERM, ROA

Sumber: Output SPSS, 2015

Berdasarkan tabel di atas, nilai $\mathrm{F}$ model penelitian diperoleh sebesar 9,201 dengan nilai signifikansi sebesar 0,000. Dari tabel distribusi F diperoleh nilai F sebesar 2,33. Nilai $F_{\text {hitung }}$ lebih besar dari $\mathrm{F}_{\text {tabel }}(9,201>2,33)$ dan tingkat signifikansi lebih kecil dari 0,05 maka dapat disimpulkan bahwa beda permanen, beda temporer, arus kas, ROA dan ukuran perusahaan secara bersama-sama memiliki pengaruh yang signifikan terhadap pertumbuhan laba. 


\section{Uji Statistik t}

Tabel 4. Hasil Uji t

\section{Coefficients $^{\mathbf{a}}$}

\begin{tabular}{|ll|r|r|} 
Model & & $\mathrm{T}$ & \\
& & & Sig. \\
& (Constant) &,- 308 &, 759 \\
& PERM & 2,481 &, 015 \\
& TEMP & 3,463 &, 001 \\
& OCF & 1,758 &, 083 \\
& ROA &,- 190 &, 850 \\
& Size &, 228 &, 821 \\
\end{tabular}

a. Dependent Variable: $\operatorname{Ln} \Delta N I$

Sumber: Output SPSS, 2015

Variabel beda permanen dari book tax differences menunjukkan nilai $\mathrm{t}$ sebesar 2,481 dengan signifikansi sebesar 0,015. Nilai signifikansi tersebut lebih kecil dari 0,05. Hal ini menunjukkan bahwa beda permanen memiliki pengaruh yang signifikan positif terhadap pertumbuhan laba. Variabel beda temporer dari book tax difference menunjukkan nilai t sebesar 3,463 dengan nilai signifikansi sebesar 0,001. Nilai signifikansi tersebut lebih kecil dari 0,05, hal tersebut menunjukkan bahwa beda temporer memiliki pengaruh yang signifikan positif terhadap pertumbuhan laba. Variabel arus kas/operating cash flow (OCF) menunjukkan nilai t sebesar 1,758 dengan signifikansi sebesar 0,083. Arus kas berpengaruh positif terhadap pertumbuhan laba perusahaan karena tingkat signifikansinya lebih kecil dari 0,10 .

Sedangkan variabel kontrolnya, yaitu Return On Assets (ROA), menunjukkan nilai t sebesar -0,190 dengan tingkat signifikansi 0,850. Ukuran perusahaan (size) menunjukkan hasil nilai t sebesar 0,288 dengan signifikansi 0,821. Baik ROA maupun ukuran perusahaan tidak berpengaruh signifikan terhadap pertumbuhan laba perusahaan karena tingkat signifikansinya lebih besar dari 0,05 .

\section{Pengaruh Beda Permanen dari Book Tax Differences terhadap Pertum- buhan Laba}

Nilai signifikansinya yaitu 0,015 yang lebih kecil dari 0,05. Artinya hipotesis 1a diterima. Beda permanen dalam penelitian ini berpengaruh signifikan positif 
terhadap pertumbuhan laba perusahaan. Artinya, semakin besar beda permanen maka pertumbuhan laba perusahaan semakin besar.

Penelitian ini mendapatkan hasil yang sama dengan penelitian yang dilakukan oleh Amelia, Zirman dan Diyanto (2014) yang mengungkapkan bahwa beda permanen berpengaruh terhadap pertumbuhan laba suatu perusahaan. Jackson (2009) juga mengungkapkan dalam jurnalnya yang berjudul "Book Tax Differences and Earning Growth" bahwa beda permanen secara signifikan berpengaruh terhadap pertumbuhan laba.

Beda permanen sebagai salah satu pembentuk book tax differences dapat mempengaruhi besar kecilnya laba bersih yang dihasilkan perusahaan. Hal ini disebabkan oleh adanya koreksi fiskal, baik koreksi positif atau negatif. Koreksi positif akan menambah laba fiskal. Semakin besar laba fiskal, beban pajak yang harus dibayarkan akan semakin besar pula dan akibatnya laba bersih akan berkurang. Sedangkan koreksi negatif berkebalikan dengan koreksi positif, dan akan mengurangi laba fiskal sehingga beban pajak yang harus dibayarkan semakin kecil. Hal ini akan mengakibatkan bertambahnya laba bersih. Sehingga, beda permanen berpengaruh terhadap pertumbuhan laba.

\section{Pengaruh Beda Temporer dari Book Tax Differences terhadap Pertum- buhan Laba}

Tingkat signifikansi dari beda temporer sebesar 0,001 atau di bawah 0,05 yang artinya beda temporer berpengaruh signifikan terhadap pertumbuhan laba, berarti hipotesis $1 \mathrm{~b}$ diterima. Beda temporer dalam penelitian ini berpengaruh signifikan positif terhadap pertumbuhan laba perusahaan. Artinya, semakin besar beda temporer maka pertumbuhan laba perusahaan semakin besar.

Beda temporer sebagai pembentuk book tax differences, sama halnya dengan beda permanen, akan menyebabkan adanya koreksi fiskal baik positif maupun negatif. Apabila dikoreksi positif, kemudian menyebabkan laba fiskal bertambah. Jika laba fiskal bertambah maka beban pajak yang harus dibayarkan akan semakin besar. Semakin besar beban pajak yang harus dibayarkan, maka akan semakin kecil laba bersih yang dihasilkan. Kebalikannya, apabila dilakukan koreksi negatif, laba fiskal akan berkurang. Berkurangnya laba fiskal akan mengakibatkan pajak yang harus dibayarkan berkurang.

Hasil penelitian ini sejalan dengan penelitian yang dilakukan oleh Brolin dan Rohman (2014) yang mengungkapkan bahwa beda temporer memiliki pengaruh signifikan terhadap pertumbuhan laba dengan arah positif. Berbeda dengan Saputro (2011), menyatakan bahwa beda temporer berpengaruh signifikan negatif terhadap pertumbuhan laba. Menurutnya, beda temporer dari book tax differences mampu memprediksi pertumbuhan laba perusahaan satu periode ke depan. 


\section{Pengaruh Arus Kas terhadap Pertumbuhan Laba}

Penelitian ini mendapatkan hasil signifikansi sebesar 0,083 untuk variabel arus kas/operating cash flow (OCF). Artinya, arus kas berpengaruh positif terhadap pertumbuhan laba. Semakin besar arus kas maka pertumbuhan laba perusahaan juga semakin besar. Taraf signifikansi yang digunakan sebesar 0,10 karena hasil signifikansi arus kas menunjukkan hasil sebesar 0,083 dimana hasil tersebut lebih besar dari 0,05 namun lebih kecil dari 0,10. Hipotesis 2 diterima.

Hal ini sesuai dengan teori yang diungkapkan oleh Hery (2009:201), bahwa informasi arus kas dapat memberikan gambaran mengenai hasil kinerja perusahaan yang sesungguhnya selama periode tertentu. Laba bersih kadang-kadang tidak memberikan gambaran yang akurat mengenai hasil kinerja perusahaan sesungguhnya selama periode tertentu. Salah satu cerminan kinerja perusahaan adalah pertumbuhan laba. Perusahaan dengan pertumbuhan laba yang tinggi, laba bersih yang dihasilkan tidak menjamin bahwa perusahaan tersebut memiliki uang kas yang cukup untuk memenuhi kebutuhan kas jangka pendeknya.

Prastowo (2011:32), juga berpendapat bahwa laporan informasi arus kas operasi dapat dijadikan alat pengecekan atas informasi laba dan sebagai pengukur kinerja perusahaan. Kinerja perusahaan ini dapat dilihat dari pertumbuhan laba perusahaan. Laporan arus kas membantu para pemakai untuk mengetahui alasanalasan perbedaan antara laba bersih atau laba akuntansi dengan laba tunainya. Informasi arus kas mungkin bermanfaat dan memiliki pengaruh terhadap pertumbuhan laba perusahaan karena laporan arus kas memberikan informasi apapun yang ingin diketahui mengenai kinerja perusahaan selama periode tertentu.

Hasil penelitian ini sejalan dengan penelitian yang dilakukan oleh Saputro (2011) yang menyatakan bahwa arus kas memiliki pengaruh yang positif terhadap pertumbuhan laba. Hasil yang sama juga diungkapkan oleh Amelia, Zirman dan Diyanto (2014) serta Oktafioni, Ethika dan Rahmawati (2012). Asma (2013) juga membuktikan bahwa arus kas berpengaruh positif terhadap persistensi laba.

\section{Pengaruh Return On Assets (ROA) sebagai Variabel Kontrol terhadap Pertumbuhan Laba}

Tingkat signifikansi ROA dalam penelitian ini sebesar 0,850 atau lebih besar dari 0,05. Artinya, ROA tidak berpengaruh signifikan terhadap pertumbuhan laba. Hasil tersebut menunjukkan bahwa hipotesis 3 ditolak. Hasil penelitian ini mendukung penelitian yang telah dilakukan oleh Oktafioni, Ethika dan Rahmawati (2012) yang menyatakan bahwa ROA tidak berpengaruh signifikan terhadap pertumbuhan laba perusahaan.

Hasil ini berbanding terbalik dengan teori yang diungkapkan oleh Dendawijaya (2003:120), yang menyatakan ROA digunakan untuk mengukur kemampuan manajemen dalam memperoleh laba secara keseluruhan. Semakin besar ROA, 
semakin besar pula tingkat keuntungan yang dicapai oleh perusahaan tersebut dan semakin baik pula posisi perusahaan tersebut dari segi penggunaan aset. Penyebab perbedaan ini mungkin karena Return On Assets (ROA) tidak selalu dapat mencerminkan pertumbuhan laba yang sebenarnya.

Hal ini disebabkan oleh ROA yang diukur dari laba bersih dibagi dengan aset rata-rata, sedangkan perusahaan bisa saja melakukan investasi aset besar-besaran, sehingga nilai aset meningkat dengan pesat. Nilai aset yang meningkat tersebut akan mengakibatkan nilai ROA semakin kecil, sehingga pertumbuhan laba tidak bisa tercermin sesuai dengan keadaan yang sebenarnya.

\section{Pengaruh Ukuran Perusahaan (Size) sebagai Variabel Kontrol terhadap Pertumbuhan Laba}

Tingkat signifikansi ukuran perusahaan dalam penelitian ini sebesar 0,821 atau lebih besar dari 0,05. Hasil ini menunjukkan bahwa ukuran perusahaan tidak berpengaruh signifikan terhadap pertumbuhan laba perusahaan, berarti hipotesis 4 ditolak. Hal yang sama diungkapkan oleh Saputro (2011), Brolin dan Rohman (2014) dan Oktafioni, Ethika dan Rahmawati (2012). Berbeda dengan penelitian yang dilakukan oleh Hutabarat (2013) yang mendapatkan hasil bahwa ukuran perusahaan berpengaruh negatif terhadap pertumbuhan laba perusahaan.

Manzon dan Plesko (dalam Martani dan Persada, 2009:8) menyatakan bahwa ukuran perusahaan dapat memberikan efek noise di mana perusahaan dapat melakukan tax planning dengan cara investasi aset yang akan memberikan manfaat pajak efektif sehingga efek dari book tax differences menjadi agak bias. Alasan ini sama dengan Return On Assets, karena ukuran perusahaan dihitung berdasarkan logaritma dari total aset perusahaan sehingga naik atau turunnya aset dapat menyebabkan berubahnya nilai ukuran perusahaan. Efeknya, ukuran perusahaan tidak selalu dapat mencerminkan keadaan yang sebenarnya dari pertumbuhan laba suatu perusahaan.

\section{SIMPULAN}

Beda permanen dari book tax differences berpengaruh positif terhadap pertumbuhan laba perusahaan. Artinya, apabila beda permanen meningkat maka pertumbuhan perusahaan juga meningkat. Penyebabnya adalah adanya koreksi fiskal yang menyebabkan berubahnya laba fiskal. Beda temporer dari book tax differences berpengaruh positif terhadap pertumbuhan laba perusahaan. Artinya, apabila beda temporer meningkat maka pertumbuhan perusahaan juga meningkat. Penyebabnya sama dengan beda permanen, yaitu adanya koreksi fiskal yang menyebabkan berubahnya laba fiskal. Arus kas berpengaruh positif terhadap pertumbuhan laba perusahaan. Artinya, apabila arus kas meningkat maka pertumbuhan perusahaan juga meningkat. Informasi arus kas dapat memberikan gambaran 
mengenai hasil kinerja perusahaan yang sesungguhnya selama periode tertentu. Return On Assets (ROA) sebagai variabel kontrol tidak berpengaruh signifikan terhadap pertumbuhan laba perusahaan, karena ROA diukur dengan aset ratarata, sehingga apabila nilai aset berubah, ROA akan berubah. Hasilnya tidak selalu mencerminkan pertumbuhan laba yang sebenarnya. Ukuran perusahaan (size) sebagai variabel kontrol tidak berpengaruh signifikan terhadap pertumbuhan laba perusahaan. Sesuai dengan teori yang diungkapkan Mazon dan Plezko, ukuran perusahaan dapat memberikan efek bias karena diukur dengan total aset, sama halnya dengan ROA. Book tax differences, arus kas, Return On Assets (ROA) dan ukuran perusahaan secara simultan berpengaruh terhadap pertumbuhan laba perusahaan.

Saran yang dapat diberikan untuk penelitian selanjutnya, Peneliti selanjutnya dapat menambah data penelitian sehingga hasil yang didapatkan bisa lebih baik dan tidak terjadi masalah dalam uji asumsi klasik. Level signifikansi dapat dinaikkan apabila hasilnya lebih besar dari 0,05 tetapi lebih kecil dari 0,10. Peneliti selanjutnya dapat menambah variabel lain yang mungkin dapat mempengaruhi pertumbuhan laba.

\section{DAFTAR PUSTAKA}

Al Quran

Asma, T.N. 2013. Pengaruh Aliran Kas dan Perbedaan Antara Laba Akuntansi dengan Laba Fiskal terhadap Persistensi Laba. Tesis. Fakultas Ekonomi Universitas Negeri Padang. Diunduh tanggal 9 Januari 2015.

Amelia, Z., dan Diyanto, V. 2013. Pengaruh Book Tax Differences, Aliran Kas, Tingkat Hutang terhadap Perubahan Laba (Studi Empiris Pada Perusahaan Real Estate and Property Yang Terdaftar di BEI 2010- 2012). JOM FEKON, Vol. 1, No 2 Oktober 2014. Diunduh tanggal 9 Januari 2015.

Brolin, A., dan Rohman, A. 2014. Pengaruh Book Tax Differences terhadap Pertumbuhan Laba. Diponegoro Journal of Accounting, Vol. 03, No. 02 Tahun 2014, Halaman 113.

Dendawijaya, L. 2003. Manajemen Perbankan. Jakarta: Ghalia Indonesia.

Hery. 2009. Akuntansi Keuangan Menengah I. Jakarta: Bumi Aksara.

Hutabarat, L.M. 2013. Pengaruh Book Tax Differences Terhadap Pertumbuhan Laba (Studi Empiris pada Perusahaan Food and Beverages yang Terdaftar di Bursa Efek Indonesia Tahun 2010-2012). Tesis. Fakultas Ekonomi Universitas Negeri Gorontalo. Diunduh tanggal 14 Oktober 2014.

Jackson, M. 2009. Book Tax Differences and Earnings Growth. Diunduh dari http://ssrn.com tanggal 11 Januari 2015.

Lestari, B. 2011. Analisis Pengaruh Book Tax Differences Terhadap Pertumbuhan Laba (Studi Empiris Pada Perusahaan Manufaktur yang Terdaftar di Bursa Efek Indonesia Tahun 2007-2009). Skripsi. Fakultas Ekonomi Universitas Negeri Diponegoro. Diunduh tanggal 9 Januari 2015. 
Martani, A., dan Persada, E. 2009. Pengaruh Book Tax Gap terhadap Persistensi Laba. Jurnal Akuntansi Universitas Indonesia. Diunduh tanggal 1 Januari 2015.

Nila, S.R. 2013. Analisis Pengaruh Risiko Pembiayaan terhadap Profitabilitas (Studi Kasus Pada Bank Muamalat Cabang Semarang). Skripsi. Institut Agama Islam Negeri Walisongo Semarang. Diunduh tanggal 29 Juni 2015.

Oktafioni, R., Ethika, dan Rahmawati, N. 2012. Pengaruh Book Tax Differences terhadap Pertumbuhan Laba (Studi Empiris Perusahaan Manufaktur Yang Terdaftar di BEI Tahun 2009-2011). Jurnal Ekonomi Universitas Bung Hatta. Diunduh tanggal 14 Oktober 2014.

Prastowo, D. 2011. Analisis Laporan Keuangan. Yogyakarta: Penerbit dan Percetakan STIM YKPN.

Saputro, N. 2011. Pengaruh Book Tax Differences terhadap Pertumbuhan Laba (Studi Empiris Pada Perusahaan Manufaktur yang Terdaftar di Bursa Efek Indonesia Tahun 2008-2010). Skripsi, Fakultas Ekonomi Universitas Diponegoro. Diperoleh tanggal 1 Desember 2014.

Wijayanti, H.T. 2006. Analisis Pengaruh Perbedaan Antara Laba Akuntansi dan Laba Fiskal terhadap Persistensi Laba, Akrual dan Arus Kas. Simposium Nasional Akuntansi IX, Padang. Diunduh tanggal 22 Februari 2015. 